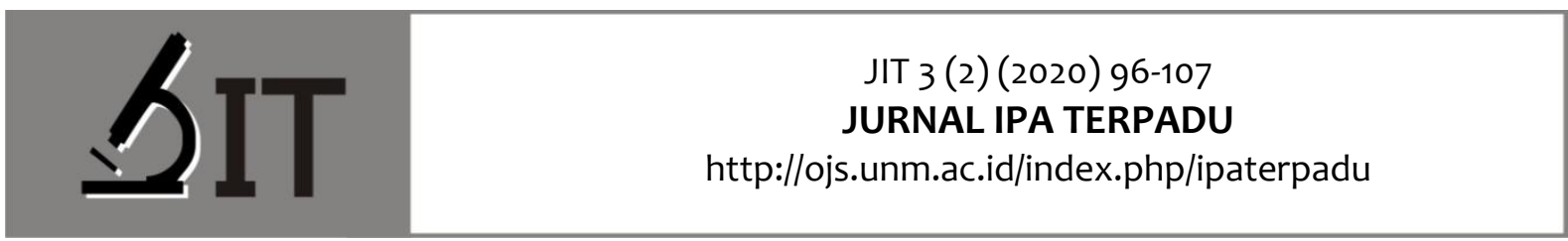

p-ISSN : 2597-8977

e-ISSN : 2597-8985

Harlina *)

Prodi Pendidikan IPA

Ramlawati

Universitas Negeri Makassar

Muhammad Aqil Rusli

Universitas Negeri Makassar

\section{DESKRIPSI KEMAMPUAN LITERASI SAINS PESERTA DIDIK KELAS IX DI SMPN 3 MAKASSAR}

Abstrak: Penelitian ini adalah penelitian survey bersifat deskriptif kuantitatif yang bertujuan untuk mendeskripsikan tingkat kemampuan literasi sains pada aspek kompetensi sains peserta didik kelas IX di SMP Negeri 3 Makassar pada materi: (1) tekanan zat; (2) sistem pernapasan manusia; (3) getaran dan gelombang; (4) cahaya dan alat optik. Populasi dalam penelitian ini adalah seluruh peserta didik kelas IX SMP Negeri 3 Makassar tahun pelajaran 2019/2020 sebanyak 349 peserta didik. Pengambilan sampel dilakukan dengan teknik sampel jenuh sehingga jumlah sampel sebanyak 349 peserta didik. Pengambilan data penelitian menggunakan instrumen tes literasi sains berupa tes pilihan ganda pada materi tekanan zat, sistem pernapasan manusia, getaran dan gelombang serta cahaya dan alat optik. Hasil penelitian yang diperoleh adalah kemampuan literasi sains pada aspek kompetensi sains peserta didik kelas IX di SMP Negeri 3 Makassar (1) pada materi tekanan zat untuk indikator mengidentifikasi masalah ilmiah tergolong "tinggi", pada indikator menjelaskan fenomena ilmiah tergolong "rendah" dan pada indikator menggunakan bukti ilmiah tergolong "sangat rendah". (2) pada materi sistem pernapasan manusia untuk indikator mengidentifikasi masalah ilmiah tergolong "rendah", pada indikator menjelaskan fenomena ilmiah tergolong "tinggi" dan pada indikator menggunakan bukti ilmiah tergolong "sangat rendah". (3) pada materi getaran dan gelombang untuk indikator mengidentifikasi masalah ilmiah dan menjelaskan fenomena ilmiah tergolong "sedang" sedangkan pada indikator menggunakan bukti ilmiah tergolong "rendah". (4) pada materi cahaya dan alat optik untuk indikator mengidentifikasi masalah ilmiah tergolong "rendah", pada indikator menjelaskan fenomena ilmiah dan menggunakan bukti ilmiah tergolong "sangat rendah". Peneliti selanjutnya diharapkan agar dapat meneliti pada aspek lain seperti aspek konteks, aspek konten atau aspek sikap literasi sains.

Kata Kunci: Kompetensi Sains, Literasi Sains.

Abstract: This research is a quantitative descriptive survey research that aims to describe the level of scientific literacy ability in aspects of science competence in class IX students at SMP Negeri 3 Makassar on the material: (1) pressure of substances; (2) human respiratory system; (3) vibrations and waves; (4) light and optical devices. The population in this study were all class IX students of SMP Negeri 3 Makassar in the academic year 2019/2020 as many as 349 students. Sampling was done by saturated sample technique so that the total sample of 349 students. Retrieval of research data using scientific literacy test instruments in the form of multiple choice tests on material pressure substances, human respiratory system, vibrations and waves as well as light and optical devices. The results obtained are the ability of scientific literacy in aspects of scientific competence of class IX students in SMP Negeri 3 Makassar (1) on material
*) Correspondence Author: harlinahaeruddin@gmail.com 
pressure for indicators to identify scientific problems classified as "high", the indicators explain scientific phenomena classified as "low" and the indicators using scientific evidence classified as "very low". (2) on the material of the human respiratory system for indicators identifying scientific problems classified as "low", the indicators explaining scientific phenomena are classified as "high" and on indicators using scientific evidence classified as "very low". (3) on vibration and wave material for indicators identify scientific problems and explain scientific phenomena classified as "medium" while those using scientific evidence are "low". (4) on light material and optical devices for indicators identifying scientific problems are classified as "low", the indicators explain scientific phenomena and use scientific evidence classified as "very low". The next researcher is expected to be able to examine other aspects such as aspects of context, aspects of content or aspects of scientific literacy.

Keywords: Science Competition, Scientific Literacy

\section{PENDAHULUAN}

Memasuki abad ke- 21 yang semakin pesat perkembangan pengetahuan maupun teknologi tentunya memiliki tantangan tersendiri, baik di lingkungan pendidikan maupun dunia kerja. Sehingga perlunya mempersiapkan generasi yang memiliki keterampilan dalam menghadapi perkembangan zaman. Salah satu keterampilan yang penting dimiliki oleh peserta didik untuk meningkatkan pengetahuan serta agar mampu bersaing di dunia kerja adalah literasi sains.

Menurut OECD (2003) secara harfiah, literasi sains terdiri dari kata yaitu literatus yang berarti melek huruf dan scientia yang diartikan memiliki pengetahuan. Literasi sains merupakan kemampuan menggunakan pengetahuan sains, mengidentifikasi pertanyaan, dan menarik kesimpulan berdasarkan bukti-bukti, dalam rangka memahami serta membuat keputusan berkenaan dengan alam dan perubahan yang dilakukan terhadap alam melalui aktivitas manusia (Yuliati, 2017).

Hal senada dikemukakan oleh Novili, Utari, Saepuzaman, \& Karim (2017) bahwa literasi sains merupakan kemampuan menggunakan pengetahuan sains, mengidentifikasi pertanyaaan dan menarik kesimpulan berdasarkan bukti-bukti, untuk memahami dan membuat keputusan yang berhubungan dengan alam dan perubahan yang dilakukan terhadap alam tersebut melalui aktivitas manusia. Jadi dapat disimpulkan bahwa literasi sains adalah kemampuan seseorang dalam memahami sains dan menerapkannya dalam kehidupan sehari-hari guna memecahkan masalah yang timbul sehingga memiliki kepekaan yang tinggi terhadap diri dan lingkungannya dalam mengambil keputusan berdasarkan pertimbangan sains.

Terdapat empat aspek yang menjadi karakteristik literasi sains diantaranya adalah (a) Konteks merupakan dimensi dari literasi sains yang mengandung pengertian situasi yang ada hubunganya dengan penerapan sains dalam kehidupan sehari-hari, yang digunakan menjadi bahan bagi aplikasi proses dan pemahaman konsep sains seperti kesehatan, sumber daya alam, mutu lingkungan, bahaya serta perkembangan mutakhir sains dan teknologi (Bahriah, 2015), (b) Konten atau pengetahuan merujuk pada konsep-konsep kunci dari sains yang diperlukan untuk memahami fenomena alam dan perubahan yang dilakukan terhadap alam melalui aktivitas manusia (Bahriah, 2015), (c) Kompetensi biasa disebut pula dengan proses sains merupakan dimensi dari literasi sains yang memiliki pengertian proses dalam menjawab suatu pertanyaan atau memecahkan masalah (Wulandari \& Sholihin, 2016). Pada tahun 2000 dan 2003, PISA menetapkan tiga aspek dari komponen kompetensi ilmiah atau proses sains yang diukur dalam literasi sains (Odja \& S.Payu, 2014). Tiga kompetensi ilmiah yang diukur dalam literasi sains yakni 
mengidentifikasi isu-isu atau pertanyaan ilmiah, menjelaskan fenomena secara ilmiah dan menggunakan bukti ilmiah (Islami, Nahadi, \& Permanasari, 2015). Dan juga (d) Sikap, Philips dalam Holbrook \& Rabbikmae menyatakan bahwa komponen sikap pada literasi sains diantaranya adalah kemandirian dalam belajar sains, kemampuan untuk berpikir ilmiah, keingintahuan, serta kemampuan untuk berpikir kritis (Anjarsari, 2014).

Kemampuan literasi sains penting dimiliki oleh setiap orang. Namun kemampuan ini belum optimal dilatihkan dalam pembelajaran IPA. Sebagai contoh pemanfaatan bahan-bahan kimia dalam kehidupan sehari-hari, tanpa diimbangi dengan pemahaman dampak pemakaiannya, maka dapat menyebabkan berbagai masalah terhadap diri sendiri, keluarga dan lingkungan. Oleh karenanya literasi sains penting dimiliki setiap peserta didik.

Alasan mengapa literasi sains penting untuk dikuasai oleh peserta didik, ialah karena berkaitan dengan bagaimana peserta didik memahami lingkungan hidup, kesehatan, ekonomi dan masalah-masalah lain yang dihadapi oleh masyarakat modern yang sangat bergantung pada teknologi dan kemajuan serta perkembangan ilmu pengetahuan (Nugraheni, Paidi, \& Triatmanto, 2017). Pentingnya literasi sains peserta didik sudah dianggap serius oleh negara-negara di luar negeri seperti Amerika dan Australia. Hal ini terbukti bahwa Amerika sudah memiliki standart khusus yaitu Benchmark for Science Literacy. Benchmark for Science Literacy merupakan standart khusus mengenai kemampuan literasi sains yang harus dimiliki siswa pada setiap grade yang berbeda. Di Australia literasi sains dijadikan sebagai tujuan pendidikan sains. Berdasarkan pemaparan tentang pentingnya literasi sains di atas maka sudah selayaknya peningkatan literasi sains peserta didik menjadi tujuan utama pendidikan sains di Indonesia saat ini (Fatmawati \& Utari, 2015).

Berdasarkan hasil Program Penilaian Pelajar Internasional (Program for International Student Assessment/PISA). Sebagaimana dikutip dari The Organization for Economic Co-operation and Development (OECD) bahwa skor peserta didik Indonesia pada kemampuan literasi sains masih jauh dibawah skor standar internasional yang ditetapkan oleh lembaga OECD yaitu 500. Adapun peringkat literasi sains Indonesia dari tahun 2000-2015 adalah sebagai berikut.

Tabel 1. Peringkat Literasi Sains Indonesia

\begin{tabular}{ccccc}
\hline Tahun & Skor rata-rata Indonesia & $\begin{array}{c}\text { Skor } \\
\text { maksimum }\end{array}$ & $\begin{array}{c}\text { Peringkat } \\
\text { Indonesia }\end{array}$ & Jumlah negara peserta \\
\hline 2000 & 393 & 500 & 38 & 41 \\
\hline 2003 & 395 & 500 & 38 & 40 \\
\hline 2006 & 393 & 500 & 50 & 57 \\
\hline 2009 & 383 & 500 & 60 & 65 \\
\hline 2012 & 375 & 500 & 64 & 65 \\
\hline 2015 & 403 & 500 & 64 & 72 \\
\hline & & & & Sumber: (Yuliati, 2017)
\end{tabular}

Berdasarkan hasil survey tersebut skor peserta didik Indonesia pada kemampuan literasi sains masih jauh dibawah skor standar internasional yang ditetapkan oleh lembaga OECD yaitu 500. Hasil penelitian Nugraheni, Paidi, \& Triatmanto (2017) di wilayah Gunung Kidul menunjukkan bahwa kemampuan literasi sains peserta didik memiliki rata-rata dalam kategori rendah. Penelitian ini sejalan dengan penelitian yang dilakukan oleh Hasasiyah, Hutomo, Subali, \& Marwoto (2019) menyatakan bahwa kemampuan literasi sains peserta didik masuk dalam kategori rendah. Hasil tes literasi sains tersebut semakin memperkuat rendahnya kemampuan literasi peserta didik di Indonesia.

Rendahnya hasil belajar sains berhubungan dengan proses pembelajaran sains yang belum memberikan peluang bagi peserta didik untuk mengembangkan kemampuan bernalarnya. 
Menurut Fraenkel (2012) faktor yang menyebabkan masih rendahnya literasi sains peserta didik Indonesia adalah peserta didik belum terlatih dalam menyelesaikan soal-soal dengan karakteristik seperti soal-soal pada PISA. Padahal untuk meningkatkan literasi sains, guru juga memerlukan perangkat evaluasi yang berbasis literasi sains (Huryah, Sumarmin, \& Effendi, 2017).

Berdasarkan hasil wawancara dengan tiga orang guru IPA kelas IX di SMP Negeri 3 Makassar, diperoleh informasi bahwa guru di SMPN 3 Makassar kurang mengetahui tentang PISA. Ketika penulis memperlihatkan soal PISA, guru kurang yakin apakah pernah melihat soal seperti itu sebelumnya dan tidak pernah membuat bentuk soal tersebut untuk persiapan ulangan harian, ujian tengah semester maupun ujian semester. Wawancara juga dilakukan dengan 5 orang peserta didik di SMP Negeri 3 Makassar hasilnya ialah peserta didik tidak suka membaca soal cerita yang panjang karena rendahnya minat peserta didik dalam membaca.

SMPN 3 Makassar merupakan sekolah yang pernah mengikuti lomba olimpiade IPA sampai di tingkat nasional. Hal itulah yang membuat penulis tertarik untuk mengetahui tingkat kemampuan literasi sains di sekolah tersebut. Selain itu, belum ada pengukuran kemampuan literasi sains yang dilakukan sebelumnya di sekolah SMPN 3 Makassar. PISA menetapkan tiga hal yang dinilai dalam aspek kompetensi/proses sains yakni, mengidentifikasi masalah ilmiah, menjelaskan fenomena ilmiah dan menggunakan bukti ilmiah (Odja \& S.Payu, 2014). Ketiga hal inilah yang juga dinilai peneliti dalam penelitian ini. Tujuan dari penelitian ini adalah untuk: (1) mendeskripsikan tingkat kemampuan literasi sains pada aspek kompetensi sains peserta didik kelas IX di SMP Negeri 3 Makassar pada materi tekanan zat; (2) mendeskripsikan tingkat kemampuan literasi sains pada aspek kompetensi sains peserta didik kelas IX di SMP Negeri 3 Makassar pada materi sistem pernapasan manusia; (3) mendeskripsikan tingkat kemampuan literasi sains pada aspek kompetensi sains peserta didik kelas IX di SMP Negeri 3 Makassar pada materi getaran dan gelombang; (4) mendeskripsikan tingkat kemampuan literasi sains pada aspek kompetensi sains peserta didik kelas IX di SMP Negeri 3 Makassar pada materi cahaya dan alat optik.

\section{METODE}

Penelitian ini merupakan penelitian survey bersifat deskriptif kuantitatif karena penelitian dilakukan hanya untuk mendeskripsikan pencapaian kemampuan literasi sains sesuai adanya tanpa menghubungkan dengan variabel lain. Penelitian ini dilaksanakan pada semester ganjil tahun pelajaran 2019/2020. Tempat penelitian berlokasi di SMP Negeri 3 Makassar.

Populasi dalam penelitian ini adalah seluruh peserta didik kelas IX di SMPN 3 Makassar berjumlah 349 peserta didik yang tersebar pada 10 kelas. Pengambilan sampel dilakukan dengan teknik sampel jenuh, dimana semua anggota populasi dipilih sebagai anggota sampel. Jadi jumlah sampel yang digunakan dalam penelitian ini yaitu 349 peserta didik. Kemampuan literasi sains peserta didik adalah skor yang diperoleh peserta didik setelah mengerjakan tes kemampuan literasi sains yang mengacu pada indikator literasi sains pada aspek kompetensi yaitu mengidentifikasi masalah ilmiah, menjelaskan fenomena ilmiah dan menggunakan bukti ilmiah.

Pengumpulan data dilakukan melalui tes berupa soal tes literasi sains berbentuk pilihan ganda sebanyak 22 nomor yang sebelumnya sudah diuji validitasnya. Data hasil penelitian dianalisis dengan menghitung persentase ketercapaian literasi sains menggunakan rumus percentages correction menurut Arikunto (2016) yang telah dimodifikasi sebagai berikut: 
$S=\frac{R}{N} \times 100$

Keterangan:

$\mathrm{S}=$ Persentase peserta didik yang menjawab soal dengan benar

$\mathrm{R}=$ jumlah peserta didik yang menjawab soal dengan benar

$\mathrm{N}=$ Jumlah seluruh peserta didik

Persentase ketercapaian literasi sains ini selanjutnya diinterpretasikan secara deskriptif berdasarkan tafsiran persentase yang dikemukakan oleh Arikunto (2016) yang telah dimodifikasi sebagai berikut:

Tabel 2. Tafsiran Persentase

\begin{tabular}{cc}
\hline Persentase & Kategori \\
\hline $80-100$ & Sangat Tinggi \\
$66-79$ & Tinggi \\
$56-65$ & Sedang \\
$40-55$ & Rendah \\
$0-39$ & Sangat Rendah \\
\hline
\end{tabular}

\section{HASIL DAN PEMBAHASAN}

1. Hasil

Hasil analisis statistik deskriptif memberikan gambaran umum mengenai kemampuan literasi sains peserta didik kelas IX SMPN 3 Makassar untuk materi tekanan zat, sistem pernapasan manusia, getaran dan gelombang serta cahaya dan alat optik. Skor peserta didik berdasarkan hasil analisis statistika deskriptif berupa skor maksimal, skor minimal, rata-rata skor, standar deviasi dan varians.

Tabel 3. Statistik Kemampuan Literasi Sains Peserta Didik SMPN 3 Makassar

\begin{tabular}{lc}
\hline \multicolumn{1}{c}{ Statistik Deskriptif } & Kemampuan Literasi Sains \\
\hline Jumlah Sampel & 349 \\
Skor Maksimal & 17 \\
Skor Minimal & 1 \\
Rata-Rata Skor & 9.81 \\
Standar Deviasi & 2,86 \\
Varians & 8,15 \\
\hline
\end{tabular}


Hasil pencapaian indikator aspek kompetensi literasi sains dapat dilihat pada Tabel 4.

Tabel 4. Hasil Pengelompokan Jawaban Peserta Didik di SMPN 3 Makassar

\begin{tabular}{|c|c|c|c|c|c|}
\hline Materi & $\begin{array}{c}\text { Indikator Aspek Kompetensi } \\
\text { Literasi Sains }\end{array}$ & $\begin{array}{l}\text { No } \\
\text { Soal }\end{array}$ & $\begin{array}{c}\text { Level } \\
\text { Kognitif }\end{array}$ & $\begin{array}{c}\text { Persentase } \\
(\%)\end{array}$ & $\begin{array}{c}\text { Rata- } \\
\text { rata (\%) }\end{array}$ \\
\hline \multirow{7}{*}{ Tekanan zat } & \multirow{2}{*}{ Mengidentifikasi masalah ilmiah } & 1 & $\mathrm{C}_{2}$ & 97,42 & \multirow{2}{*}{70,06} \\
\hline & & 2 & $C_{3}$ & 42,69 & \\
\hline & \multirow{2}{*}{ Menjelaskan fenomena ilmiah } & 3 & $C_{3}$ & 37,25 & \multirow{2}{*}{50,43} \\
\hline & & 4 & $\mathrm{C}_{3}$ & 56,73 & \\
\hline & \multirow{3}{*}{ Menggunakan bukti ilmiah } & 5 & $\mathrm{C}_{4}$ & 11,46 & \multirow{3}{*}{26,36} \\
\hline & & 6 & $C_{3}$ & 22,35 & \\
\hline & & 7 & $C_{3}$ & 45,27 & \\
\hline \multirow{6}{*}{$\begin{array}{l}\text { Sistem } \\
\text { pernapasan } \\
\text { manusia }\end{array}$} & \multirow{2}{*}{ Mengidentifikasi masalah ilmiah } & 8 & $\mathrm{C} 2$ & 70,49 & \multirow{2}{*}{45,13} \\
\hline & & 9 & $C_{3}$ & 19,77 & \\
\hline & \multirow{2}{*}{ Menjelaskan fenomena ilmiah } & 10 & $\mathrm{C}_{2}$ & 74,79 & \multirow{2}{*}{69,63} \\
\hline & & 11 & $\mathrm{C}_{3}$ & 64,47 & \\
\hline & \multirow{2}{*}{ Menggunakan bukti ilmiah } & 12 & $C_{3}$ & 30,09 & \multirow{2}{*}{33,10} \\
\hline & & 13 & $\mathrm{C}_{2}$ & 36,10 & \\
\hline \multirow{4}{*}{$\begin{array}{l}\text { Getaran } \\
\text { gelombang }\end{array}$} & Mengidentifikasi masalah ilmiah & 14 & $\mathrm{C} 2$ & 65,04 & 65,04 \\
\hline & Menjelaskan fenomena ilmiah & 15 & $\mathrm{C} 2$ & 59,89 & 59,89 \\
\hline & \multirow{2}{*}{ Menggunakan bukti ilmiah } & 16 & $\mathrm{C}_{4}$ & 47,85 & \multirow{2}{*}{52,44} \\
\hline & & 17 & $\mathrm{C}_{2}$ & 57,02 & \\
\hline \multirow{5}{*}{$\begin{array}{l}\text { Cahaya dan alat } \\
\text { optik }\end{array}$} & \multirow{2}{*}{ Mengidentifikasi masalah ilmiah } & 18 & $\mathrm{C}_{2}$ & 62,75 & \multirow{2}{*}{40,26} \\
\hline & & 19 & $\mathrm{C} 2$ & 17,77 & \\
\hline & Menjelaskan fenomena ilmiah & 20 & $C_{3}$ & 9,46 & 9,46 \\
\hline & \multirow{2}{*}{ Menggunakan bukti ilmiah } & 21 & $\mathrm{C}_{2}$ & 37,54 & \multirow{2}{*}{25,94} \\
\hline & & 22 & $\mathrm{C}_{2}$ & 14,33 & \\
\hline
\end{tabular}

Berdasarkan Tabel 4 persentase jawaban benar peserta didik dalam menjawab soal pada materi tekanan zat, dapat disajikan dalam bentuk diagram batang dalam Gambar 1.

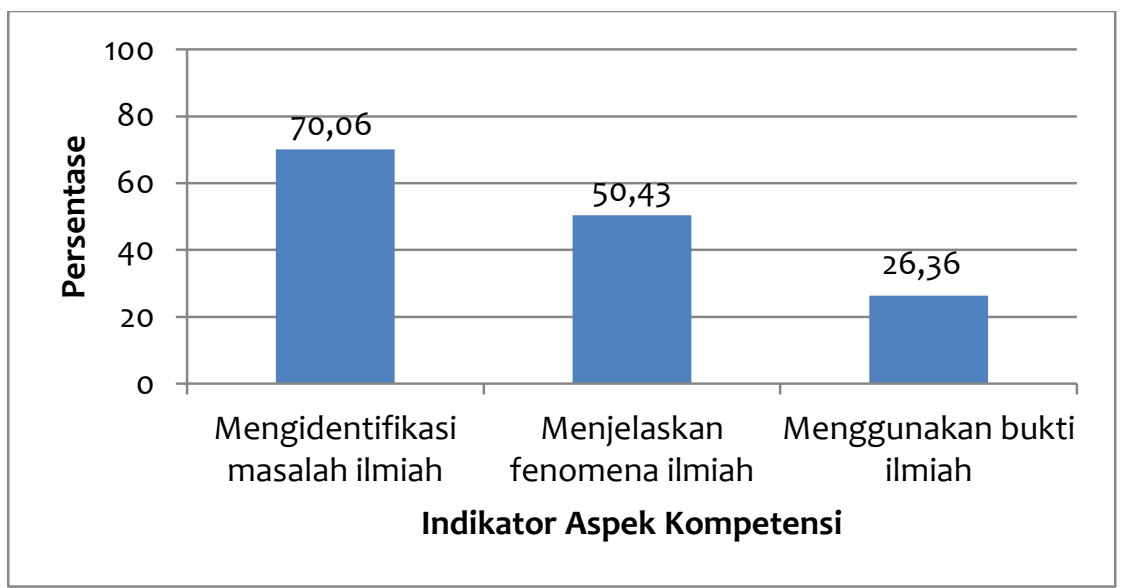

Gambar 1. Diagram Batang Persentase Jumlah Peserta Didik yang Menjawab Benar Soal Literasi Sains pada Materi Tekanan Zat 
Berdasarkan Tabel 4 persentase jawaban benar peserta didik dalam menjawab soal pada materi sistem pernapasan manusia, dapat disajikan dalam bentuk diagram batang dalam Gambar 2.

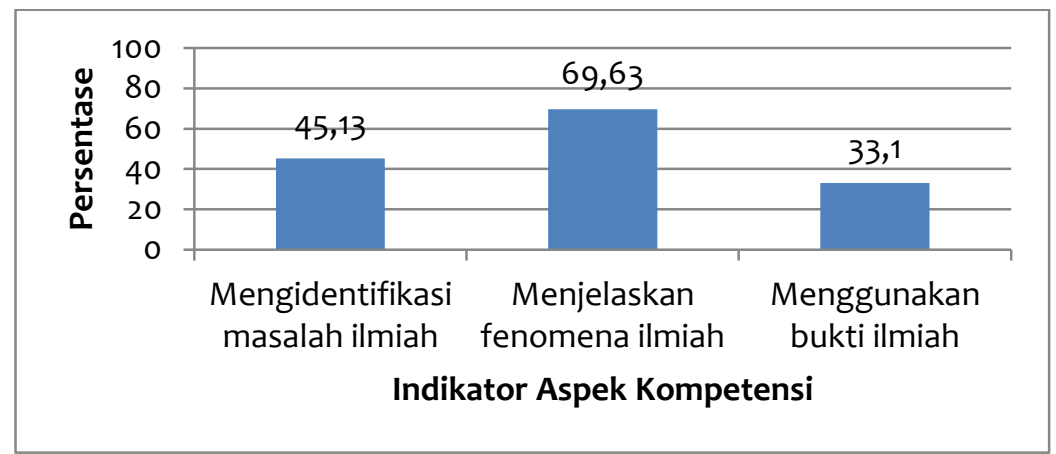

Gambar 2. Diagram Batang Persentase Jumlah Peserta Didik yang Menjawab Benar Soal Literasi Sains pada Materi Sistem Pernapasan Manusia

Berdasarkan Tabel 4 persentase jawaban benar peserta didik dalam menjawab soal pada materi getaran dan gelombang, dapat disajikan dalam bentuk diagram batang dalam Gambar 3 .

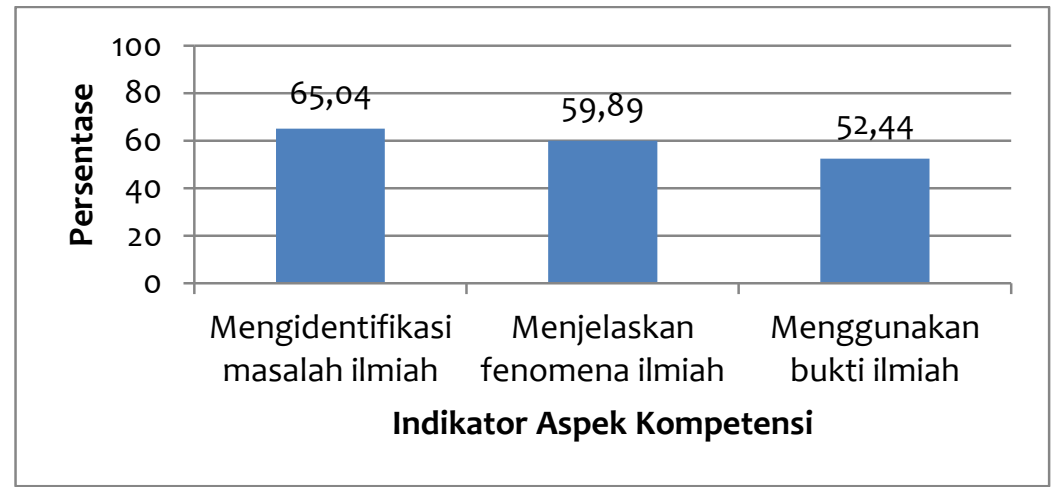

Gambar 3. Diagram Batang Persentase Jumlah Peserta Didik yang Menjawab Benar Soal Literasi Sains pada Materi Getaran dan Gelombang

Berdasarkan Tabel 4 persentase jawaban benar peserta didik dalam menjawab soal pada materi cahaya dan alat optik, dapat disajikan dalam bentuk diagram batang dalam Gambar 4 .

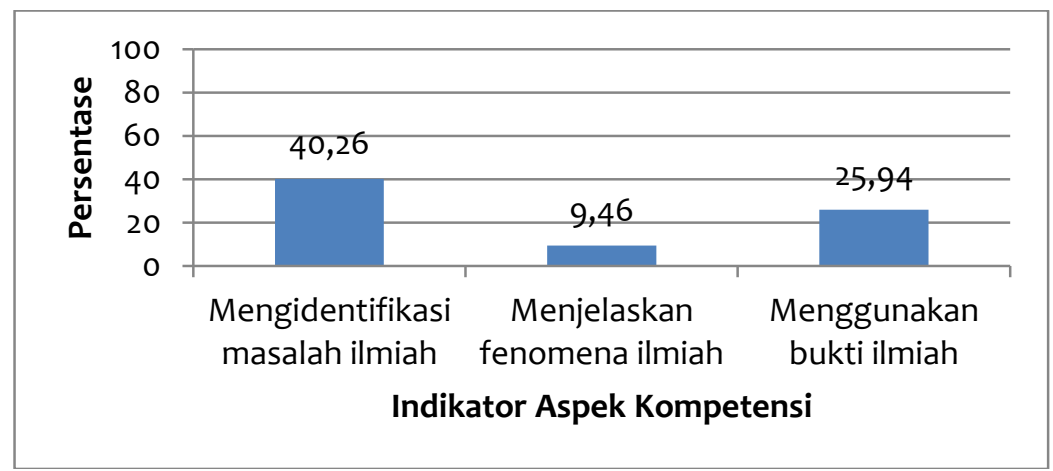

Gambar 4. Diagram Batang Persentase Jumlah Peserta Didik yang Menjawab Benar Soal Literasi Sains pada Materi Cahaya dan Alat Optik 


\section{Pembahasan}

\section{a. Deskripsi Kemampuan Literasi Sains pada Materi Tekanan Zat}

Berdasarkan Tabel 4 diperoleh informasi bahwa, aspek kompetensi mengidentifikasi masalah ilmiah pada materi tekanan zat, tersebar pada nomor soal 1 dan 2. Persentase peserta didik yang menjawab benar pada soal nomor 1 adalah 97,42\% sedangkan pada soal nomor 2 adalah 42,69\%. Perbedaan persentase ini dikarenakan kedua soal berada pada level kognitif yang berbeda. Soal nomor 1 berada pada level kognitif $C_{2}$ sehingga lebih mudah dijawab peserta didik dibandingkan dengan soal nomor 2 yang berada pada level kognitif C3. Rata-rata persentase dari kedua soal sebesar 70,06\%, setelah ditafsirkan berdasarkan tafsiran Arikunto (2016), maka kemampuan literasi sains peserta didik pada aspek kompetensi mengidentifikasi masalah ilmiah pada materi tekanan berada pada kategori "tinggi". Hal ini menggambarkan bahwa kemampuan peserta didik sudah bagus dalam mengenal masalah dan ciri-ciri kunci dari situasi yang terdapat dalam soal (Asyhari \& Hartati, 2015).

Aspek kompetensi menjelaskan fenomena ilmiah tersebar pada nomor soal 3 dan 4. Persentase peserta didik yang menjawab benar pada soal nomor 3 adalah 37,25\% sedangkan pada soal nomor 4 adalah 56,73\%. Meskipun kedua soal berada pada level kognitif yang sama yaitu C3 namun terdapat perbedaan persentase yang cukup jauh. Peserta didik lebih banyak menjawab benar soal nomor 4 dibandingkan soal nomor 3. Hal ini menggambarkan peserta didik lebih memahami penerapan konsep hidrostatis daripada hukum Archimedes dalam kehidupan seharihari. Rata-rata persentase dari kedua soal sebesar 50,43\% berdasarkan tafsiran, kemampuan literasi sains peserta didik pada aspek kompetensi menjelaskan fenomena ilmiah pada materi tekanan berada pada kategori "rendah". Hal ini menggambarkan bahwa peserta didik kurang memahami konsep materi sehingga belum optimal dalam mengaplikasikan pengetahuan yang dimilikinya berdasarkan fenomena yang terjadi di sekitar mereka (Wulandari \& Sholihin, 2016).

Aspek kompetensi menggunakan bukti ilmiah tersebar pada nomor soal 5, 6, dan 7 . Persentase peserta didik yang menjawab benar pada soal nomor 5 adalah $11,46 \%$. Persentase peserta didik yang menjawab benar pada soal nomor 6 adalah 22,35\% sedangkan pada soal nomor 7 adalah 45,27\%. Soal nomor 5 yang paling rendah persentasenya, hal ini dikarenakan soal ini merupakan soal $\mathrm{C}_{4}$, sementara soal nomor 6 dan 7 adalah level kognitif C3. Meskipun tingkatan kedua soal tersebut sama, namun terdapat perbedaan persentase yang cukup jauh. Peserta didik lebih banyak menjawab benar soal nomor 7 dibandingkan soal nomor 6 . Hal ini menggambarkan peserta didik kurang memahami penerapan konsep hukum Pascal dalam kehidupan sehari-hari. Rata-rata persentase dari ketiga soal sebesar $26,36 \%$ berdasarkan tafsiran, kemampuan literasi sains peserta didik pada aspek kompetensi menggunakan bukti ilmiah pada materi tekanan berada pada kategori " sangat rendah". Hal ini menggambarkan kemampuan peserta didik yang belum optimal dalam menafsirkan bukti ilmiah ataupun menarik kesimpulan dari data-data yang disajikan dalam soal. Dengan kata lain, peserta didik belum mampu menggambarkan hubungan yang jelas dan logis antara bukti dan kesimpulan atau keputusan (Wulandari \& Sholihin, 2016).

\section{b. Deskripsi Kemampuan Literasi Sains pada Materi Sistem Pernapasan Manusia}

Berdasarkan Tabel 4 diperoleh informasi bahwa, aspek kompetensi mengidentifikasi masalah ilmiah pada materi sistem pernapasan manusia tersebar pada nomor soal 8 dan 9 . Persentase peserta didik yang menjawab benar pada soal nomor 8 adalah $70,49 \%$ sedangkan pada soal nomor 9 adalah $19,77 \%$. Perbedaan persentase ini dikarenakan kedua soal berada pada level kognitif yang berbeda. Soal nomor 8 berada pada level kognitif C2 sehingga lebih mudah dijawab peserta didik dibandingkan dengan soal nomor 9 yang berada pada level kognitif C3. Rata-rata persentase dari kedua soal sebesar $45,13 \%$ berdasarkan tafsiran, kemampuan literasi sains peserta 
didik pada aspek kompetensi mengidentifikasi masalah ilmiah pada materi sistem pernapasan manusia berada pada kategori "rendah". Hal ini menggambarkan bahwa kemampuan peserta didik masih kurang dalam mengenal masalah dan ciri-ciri kunci dari situasi yang terdapat dalam soal (Asyhari \& Hartati, 2015).

Aspek kompetensi menjelaskan fenomena ilmiah tersebar pada nomor soal 10 dan 11. Persentase peserta didik yang menjawab benar pada soal nomor 10 adalah $74,79 \%$ sedangkan pada soal nomor 11 adalah $64,47 \%$. Kedua soal berada pada level kognitif yang sama yaitu C3. Ratarata persentase dari kedua soal sebesar $69,63 \%$ berdasarkan tafsiran, kemampuan literasi sains peserta didik pada aspek kompetensi menjelaskan fenomena ilmiah pada materi sistem pernapasan manusia berada pada kategori "tinggi". Hal ini menggambarkan bahwa peserta didik sudah memahami konsep materi yang dipelajari dan mampu mengaplikasikannya dalam situasi di sekitar mereka (Wulandari \& Sholihin, 2016).

Aspek kompetensi menggunakan bukti ilmiah tersebar pada nomor soal 12 dan 13. Persentase peserta didik yang menjawab benar pada soal nomor 12 adalah 30,09\%. Persentase peserta didik yang menjawab benar pada soal nomor 13 adalah 36,10\%. Soal nomor 13 berada pada level kognitif $C_{2}$ sehingga lebih mudah dijawab peserta didik dibandingkan dengan soal nomor 12 yang berada pada level kognitif C3. Rata-rata persentase dari ketiga soal sebesar 33,10\%. Berdasarkan tafsiran, kemampuan literasi sains peserta didik pada aspek kompetensi menggunakan bukti ilmiah pada materi tekanan berada pada kategori " sangat rendah". Hal ini menggambarkan kemampuan peserta didik yang belum optimal dalam menafsirkan bukti ilmiah ataupun menarik kesimpulan dari data-data yang disajikan dalam soal. Dengan kata lain, peserta didik belum mampu menggambarkan hubungan yang jelas dan logis antara bukti dan kesimpulan atau keputusan (Wulandari \& Sholihin, 2016).

\section{c. Deskripsi Kemampuan Literasi Sains pada Materi Getaran dan Gelombang}

Berdasarkan Tabel 4 diperoleh informasi bahwa, aspek kompetensi mengidentifikasi masalah ilmiah pada materi getaran dan gelombang tersebar pada nomor soal 14 . Persentase peserta didik yang menjawab benar pada soal tersebut adalah $65,04 \%$. Soal nomor 14 berada pada level kognitif $C_{2}$ sehingga lebih mudah dijawab peserta didik. Berdasarkan tafsiran, kemampuan literasi sains peserta didik pada aspek kompetensi mengidentifikasi masalah ilmiah pada materi sistem pernapasan manusia berada pada kategori "sedang". Hal ini menggambarkan bahwa kemampuan peserta didik cukup baik dalam mengenal masalah dan ciri-ciri kunci dari situasi yang terdapat dalam soal (Asyhari \& Hartati, 2015).

Aspek kompetensi menjelaskan fenomena ilmiah tersebar pada nomor soal 15. Persentase peserta didik yang menjawab benar pada soal tersebut adalah 59,89\%. Soal nomor 15 berada pada level kognitif C2 sehingga lebih mudah dijawab peserta didik. Berdasarkan tafsiran, kemampuan literasi sains peserta didik pada aspek kompetensi menjelaskan fenomena ilmiah pada materi getaran dan gelombang berada pada kategori "sedang". Hal ini menggambarkan bahwa peserta didik cukup memahami konsep materi yang dipelajari dan mampu mengaplikasikannya dalam situasi di sekitar mereka (Wulandari \& Sholihin, 2016).

Aspek kompetensi menggunakan bukti ilmiah tersebar pada nomor soal 16 dan 17. Persentase peserta didik yang menjawab benar pada soal nomor 16 adalah 47,85\%. Persentase peserta didik yang menjawab benar pada soal nomor 17 adalah 57,02\%. Peserta didik lebih banyak menjawab benar soal nomor 17 dibandingkan soal nomor 16 . Hal ini dikarenakan soal nomor 17 berada pada level kognitif $\mathrm{C}_{2}$ sehingga lebih mudah dijawab peserta didik dibandingkan dengan soal nomor 16 yang berada pada level kognitif $C_{4}$. Rata-rata persentase dari kedua soal sebesar 52,44\%. Berdasarkan tafsiran, kemampuan literasi sains peserta didik pada aspek kompetensi menggunakan bukti ilmiah pada materi getaran dan gelombang berada pada kategori "rendah". Hal ini menggambarkan kemampuan peserta didik yang belum optimal dalam menafsirkan bukti 
ilmiah ataupun menarik kesimpulan dari data-data yang disajikan dalam soal. Dengan kata lain, peserta didik belum mampu menggambarkan hubungan yang jelas dan logis antara bukti dan kesimpulan atau keputusan (Wulandari \& Sholihin, 2016).

\section{d. Deskripsi Kemampuan Literasi Sains pada Materi Cahaya dan Alat Optik}

Berdasarkan Tabel 4 diperoleh informasi bahwa aspek kompetensi mengidentifikasi masalah ilmiah pada materi cahaya dan alat optik tersebar pada nomor soal 18 dan 19. Persentase peserta didik yang menjawab benar pada soal nomor 18 adalah 62,75\%. Sedangkan persentase peserta didik yang menjawab benar pada soal nomor 19 adalah 17,77\%. Meskipun kedua soal berada pada level kognitif yang sama yaitu $C_{2}$ namun terdapat perbedaan persentase yang sangat jauh. Peserta didik lebih banyak menjawab benar soal nomor 18 dibandingkan soal nomor 19 . Hal ini dikarenakan peserta didik kurang memahami peristiwa fatamorgana yang dikaitkan dengan materi pembiasan cahaya. Rata-rata persentase dari kedua soal sebesar 40,26\%. Berdasarkan tafsiran, kemampuan literasi sains peserta didik pada aspek kompetensi mengidentifikasi masalah ilmiah pada materi cahaya dan alat optik berada pada kategori "rendah". Hal ini menggambarkan bahwa kemampuan peserta didik masih kurang dalam mengenal masalah dan ciri-ciri kunci dari situasi yang terdapat dalam soal (Asyhari \& Hartati, 2015).

Aspek kompetensi menjelaskan fenomena ilmiah tersebar pada nomor soal 20. Persentase peserta didik yang menjawab benar pada soal tersebut adalah 9,46\%. Soal nomor 20 berada pada level kognitif C3 namun persentase peserta didik yang menjawab benar sangan kecil. Hal ini disebabkan karena terdapat 200 peserta didik yang tidak menjawab soal. Berdasarkan tafsiran, kemampuan literasi sains peserta didik pada aspek kompetensi menjelaskan fenomena ilmiah pada materi cahaya dan alat optik berada pada kategori "sangat rendah". Hal ini menggambarkan bahwa peserta didik tidak memahami materi sehingga belum optimal dalam mengaplikasikan pengetahuan yang dimilikinya berdasarkan fenomena yang terjadi di sekitar mereka (Wulandari \& Sholihin, 2016).

Aspek kompetensi menggunakan bukti ilmiah tersebar pada nomor soal 21 dan 22 . Persentase peserta didik yang menjawab benar pada soal nomor 21 adalah 37,54\%. Persentase peserta didik yang menjawab benar pada soal nomor 22 adalah 14,33\%. Meskipun kedua soal berada pada level kognitif yang sama yaitu $C_{2}$ namun terdapat perbedaan persentase yang sangat jauh. Peserta didik lebih banyak menjawab benar soal nomor 21 dibandingkan soal nomor 22. Hal ini dikarenakan terdapat 230 peserta didik yang tidak menjawab soal. Rata-rata persentase dari kedua soal sebesar $25,94 \%$. Berdasarkan tafsiran, kemampuan literasi sains peserta didik pada aspek kompetensi menggunakan bukti ilmiah pada materi cahaya dan alat optik berada pada kategori "sangat rendah". Hal ini menggambarkan kemampuan peserta didik yang belum optimal dalam menafsirkan bukti ilmiah ataupun menarik kesimpulan dari data-data yang disajikan dalam soal. Dengan kata lain, peserta didik belum mampu menggambarkan hubungan yang jelas dan logis antara bukti dan kesimpulan atau keputusan (Wulandari \& Sholihin, 2016).

\section{KESIMPULAN}

Berdasarkan hasil penelitian dan pembahasan, dapat ditarik kesimpulan sebagai berikut:

1. Kemampuan literasi sains pada aspek kompetensi sains peserta didik kelas IX di SMP Negeri 3 Makassar pada materi tekanan zat untuk indikator mengidentifikasi masalah ilmiah tergolong tinggi, pada indikator menjelaskan fenomena ilmiah tergolong rendah dan pada indikator menggunakan bukti ilmiah tergolong sangat rendah.

2. Kemampuan literasi sains pada aspek kompetensi sains peserta didik kelas IX di SMP Negeri 3 Makassar pada materi sistem pernapasan manusia untuk indikator mengidentifikasi masalah 
ilmiah tergolong rendah, pada indikator menjelaskan fenomena ilmiah tergolong tinggi dan pada indikator menggunakan bukti ilmiah tergolong sangat rendah.

3. Kemampuan literasi sains pada aspek kompetensi sains peserta didik kelas IX di SMP Negeri 3 Makassar pada materi getaran dan gelombang untuk indikator mengidentifikasi masalah ilmiah dan menjelaskan fenomena ilmiah tergolong sedang sedangkan pada indikator menggunakan bukti ilmiah tergolong rendah.

4. Kemampuan literasi sains pada aspek kompetensi sains peserta didik kelas IX di SMP Negeri 3 Makassar pada materi cahaya dan alat optik untuk indikator mengidentifikasi masalah ilmiah tergolong rendah, pada indikator menjelaskan fenomena ilmiah dan menggunakan bukti ilmiah tergolong sangat rendah.

\section{DAFTAR PUSTAKA}

Anjarsari, P. (2014). Literasi Sains dalam Kurikulum dan Pembelajaran IPA SMP. Prosiding Semnas Pensa VI, (hal. 602-607).

Arikunto, S. (2016). Dasar - Dasar Evaluasi Pendidikan Edisi Kedua. Jakarta: Bumi Aksara.

Asyhari, A., \& Hartati, R. (2015). Profil Peningkatan Kemampuan Literasi Sains Siswa Melalui Pembelajaran Saintifik. Jurnal Ilmiah Pendidikan Fisika, Vol 4 No 2, 179-191.

Bahriah, E. S. (2015). Peningkatan Literasi Sains Calon Guru Kimia pada Aspek Konteks Aplikasi dan Proses Sains. EDUSAINS, Vol 7 No 01, 11-17.

Fatmawati, I. N., \& Utari, S. (2015). Penerapan Levels of Inquiry untuk Meningkatkan Literasi Sains Siswa SMP Tema Limbah dan Upaya Penanggulangannya. EDUSAINS, Vol 7 No 02, 152-159.

Hasasiyah, S. H., Hutomo, B. A., Subali, B., \& Marwoto, P. (2019). Analisis Kemampuan Literasi Sains Siswa SMP pada Materi Sirkulasi Darah. Jurnal Penelitian Pendidikan IPA, Vol 6 No 1, 5-9.

Huryah, F., Sumarmin, R., \& Effendi, J. (2017). Analisis Capaian Literasi Sains Biologi Siswa SMA Kelas X Di Kota Padang. Jurnal Eksakta Pendidikan (JEP), Vol 1 No 2, 72-79.

Islami, R. A., Nahadi, \& Permanasari, A. (2015). Hubungan Literasi Sains dan Kepercayaan Diri Siswa pada Konsep Asam Basa. Jurnal Penelitian dan Pembelajaran IPA, Vol 1 No 1, 16-25.

Novili, W. I., Utari, S., Saepuzaman, D., \& Karim, S. (2017). Penerapan Scientific Approach dalam Upaya Melatihkan Literasi Saintifik dalam Domain Kompetensi dan Domain Pengetahuan Siswa SMP pada Topik Kalor. Jurnal Penelitian Pembelajaran Fisika, Vol 8 No 1, 57-63.

Nugraheni, N. C., Paidi, \& Triatmanto. (2017). Kemampuan Literasi Sains Kelas X SMA Negeri Mata Pelajaran Biologi Berdasarkan Topografi Wilayah Gunungkidul. Jurnal Prodi Pendidikan Biologi, Vol 6 No 5, 261-271.

Odja, A. H., \& S.Payu, C. (2014). Analisis Kemampuan Awal Literasi Sains Siswa pada Konsep IPA. Prosiding Seminar Nasional Kimia, (hal. 40-47).

Wulandari, N., \& Sholihin, H. (2016). Analisis Kemampuan Literasi Sains pada Aspek Pengetahuan dan Kompetensi Sains Siswa SMP pada Materi Kalor. EDUSAINS, Vol 8 No 1, 66-73.

Yuliati, Y. (2017). Literasi Sains Dalam Pembelajaran IPA. Jurnal Cakrawala Pendas, Vol 3 No 2, 21-28. 


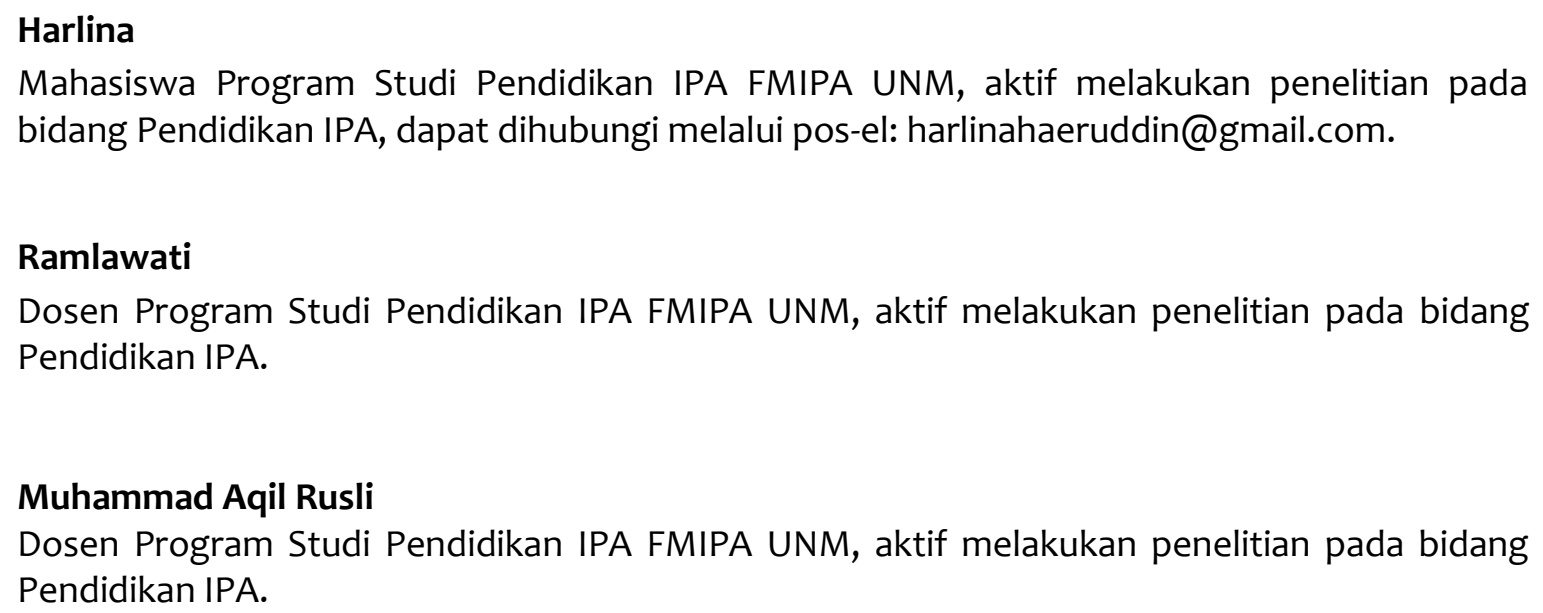

\section{Ramlawati}

Dosen Program Studi Pendidikan IPA FMIPA UNM, aktif melakukan penelitian pada bidang Pendidikan IPA.

\section{Muhammad Aqil Rusli}

Dosen Program Studi Pendidikan IPA FMIPA UNM, aktif melakukan penelitian pada bidang Pendidikan IPA. 